\title{
Harvest Handling and Postharvest Conditions for Optimum Nutrient Quality in Mango: Minerals and Vitamins
}

\author{
"MOYIB, OK; OMOTOLA, OE; BANJOKO, OO, EZIKE, BU
}

\author{
Department of Chemical Sciences, Tai Solarin University of Education, Ijagun, PMB 2118, Ijebu-Ode, Nigeria. Nigeria \\ *Corresponding Author Email: moyibok@tasued.edu.ng; kmoyib@hotmail.com, Tel: (+234) 09063491211; 07019595255
}

\begin{abstract}
Good practices at harvest and postharvest could be useful in obtaining nutritious mango with high minerals and vitamins. The present study evaluated effect of harvest handling and postharvest conditions on the level of minerals and vitamins using standard methods. Ripe, half-ripe and unripe mangoes were harvested on parent plant and on ground around parent plant. The half-ripe and unripe mangoes were further divided to include heat ripened mangoes. The mango samples were separately stored naturally at $25 \pm 3^{\circ} \mathrm{C}$ and heat ripened at $37 \pm 5^{\circ} \mathrm{C}$ for 0 to 10 day after harvest (dah). The results show Ijebu-Mamu mangoes could cater for reference dietary intake of Vit C. Mango harvested on parent plant has highest level of minerals and vitamins than those picked on ground. Ripe mango has highest level of minerals, halfripe mango presented highest level of vits. $B_{1}$ and $B_{2}$ and unripe mango has highest level of Fe and Vit. C. Heat caused increased level of minerals and reduced level of vitamins. The minerals show increased level from 0 to 4 or 6 dah while vitamins reduced from 0 till 10 dah. High level of minerals and vitamins was obtained with optimum integrated harvest and postharvest condition of half-ripe mango naturally ripened at 6 dah. The present results highlight effects of the assessed harvest handling and postharvest conditions and their co-optimization that might be necessary for high minerals and vitamins in mango.
\end{abstract}

\section{DOI: https://dx.doi.org/10.4314/jasem.v25i5.26}

Copyright: Copyright $\odot 2021$ Moyib et al. This is an open access article distributed under the Creative Commons Attribution License (CCL), which permits unrestricted use, distribution, and reproduction in any medium, provided the original work is properly cited.

Dates: Received: 20 March 2021; Revised: 27 April 2021; Accepted: 07 May 2021

Keywords: Harvest handling and postharvest conditions, mango, minerals and vitamins,

Mango, Mangifera indica, belongs to Anacardiaceae of cashew family with about 83 genera consisting 860 species of fruiting trees. Mango is a large evergreen tree that grows to a height of $10-45 \mathrm{~m}$; dome shaped with dense foliage and heavy branched from a stout trunk (Shah et al., 2010). The fruit takes four to five months from flowering to ripen and is reported to bear fruits twice a year (Ahmed and Ahmed, 2014). The fruit is a large drupe with variation in shape and size, contains a thick yellow pulp, single seed and thick yellowish-red skin when ripe. Globally, mango is generally harvested green and then commercialised after a period of storage and as a climacteric fruit has a short shelf life and respiration peak of ripening process by 3 to 4 dah at ambient temperature (Narayana et al., 1996; Roy et al., 2019). In Nigeria, harvesting of mango fruits on parent plants before becoming fully ripened is a common handling process among farmers and traders in urban cities and if unripe are kept under heat and sold gradually as becoming ripened. At village settings, mangoes are harvested when ripened on the parent plants or naturally dropped, for home consumption and sales at local markets. Mango (Mangifera indica) is a global fruit for food, feed and folklore medicine and is regarded as the king of fruits and second most traded tropical fruits in the world due to its chemical and nutrient compositions. Mango is reported to be rich in water, sugars, fibre, minerals, vitamins, and antioxidants (Ara et al., 2014; Torres-Leon et. al., 2016) with various food products derived from it, such as pulp, beverage, wine, yoghurt, toffee, custard, and ice cream. Its peel, seed and kernel are reported to be rich in phytochemicals and possess antioxidant properties use in food, drink, and beverage preparations (Ravani and Joshi, 2013). Interestingly, mango has been an important herb in the Ayurveda medicine and its juice is use as a restorative tonic for heat stroke treatment (Shah et al., 2010). Its peel is use as animal feeds while seed, bark and leaves are use as folklore medicine in Nigeria. Thus, mango has the potential to serve as a millennial nutritious, healthy and safe food due to its rich content as mentioned above. However, various pre and postharvest conditions are reported to affect nutrient quality of mango and many techniques are developed to optimise these conditions for its best postharvest management for consumer acceptance. Subsequently, temperature and dah are found as key co-factors that affect mango nutrient quality and organoleptic properties (Baloch and Bibi, 2012; Herianus et al., 2003; Joshi et al., 2017; Lee and Kader, 2000; Normand et al., 2015; Okoth et al., 2013;

*Corresponding Author Email: moyibok@tasued.edu.ng; kmoyib@hotmail.com, Tel: (+234) 09063491211; 07019595255 
Salvia-Trujillo et al., 2011). Also, mango is considered to be consumed at all stages of fruit development from the tiny immature to the fully mature fruit and its nutritional value is reported to differ with varieties and developmental stages including maturity and ripening (Ravani and Joshi, 2013). However, these studies are mostly on organoleptic and functional properties but are scantily available on mineral and vitamin level of mango fruits and at harvest handling conditions. Furthermore, suitable integrated harvest handling and postharvest conditions to have the best nutrient quality in mango has not been recognized. Consequently, the present study was carried out to evaluate harvest handling and postharvest conditions on the level of selected minerals and vitamins in mango fruits obtained from Ijebu-Mamu farmland Ijebu-North, Ogun State, Nigeria.

\section{MATERIALS AND METHODS}

Study Area: Ijebu-Mamu farmland along Ijebu-OdeIbadan high way, Ijebu-North, Ogun State, geographical coordinates Latitude $7^{\circ} 5^{`} 0^{\prime}$ “ North and Longitude $3^{\circ} 55^{\prime} 0^{\prime \prime}$ East was chosen for the study because it is a major ancient farmland and its farm produces serves over 100 Ijebu communities.

Sample Collection and Preparation: Harvest and Handling conditions: The harvest was conducted during 2017/2018 season. Matured ripe, half-ripe, and unripe mango fruits were hand-plucked on parent plants (Before dropping) and also, hand-picked on the ground around parent plants (after dropping). The before dropping mango samples were labelled accordingly: ripe mango on plant (RMP), half-ripe mango on plant (R2MP) and unripe mango on plant (UMP) and after dropping as ripe on ground (RMG), half-ripe mango on ground (R2MG) and unripe mango on ground (UMG). The R2MP, R2MG, UMP and UMG samples were further divided to include heat ripen samples, half-ripe mango on plant heat ripened (R2MPHR), half-ripe mango on ground heat ripen (R2MGHR), unripe mango on plant heat ripened (UMPHR), and unripe mango on ground heat ripened (UMGHR). The mango samples were kept in sterile polythene bags and immediately transported into the Laboratory of Department of Chemical Sciences, Tai Solarin University of Education, Ijagun, Ogun State, Nigeria.

Postharvest conditions: At the destination, the RMP, R2MP, UMP, RMG, R2MG, and UMG, samples were kept on shelf at ambient temperature $25 \pm 3^{\circ} \mathrm{C}$ and relative humidity $(\mathrm{RH}), 80 \pm 11 \%$ while the R2MPHR,
UMPHR R2MGHR, and UMGHR samples were wrapped in polyester sacks, placed in local baskets and kept in a closed dark room with a temperature range of $35 \pm 5^{\circ} \mathrm{C}$ and $55 \pm 7 \% \mathrm{RH}$ and both were stored at 0 to 10 dah. Preparation of samples: Three fruit samples from each of RMP, R2MP, R2MPHR, UMP, UMPHR, RMG, R2MGR, R2MGHR, UMG, and UMGHR, visually observed to be healthy, devoid of wounds and signs of spoilage were selected for nutritional analysis. The selected samples were washed under tap, peeled and the fleshy pulp cut into pieces using sterilized stainless knife. One and ten grams of fleshy pulp sample was crushed into pulp and stored in labelled amber bottle for immediate analysis of minerals and vitamins, respectively.

Collection of data: Data are collected every 2 dah over 0 -10dah for ripening status, minerals and vitamins in three replicates at the Laboratory of Chemical Science.

Reagents: Deionised water, distilled water, dichloroethene, hydrochloric acid $(\mathrm{HCl})$, trioxonitrate (v) acid, tetraoxosulphate vi acid $\left(\mathrm{H}_{2} \mathrm{SO}_{4}\right)$, sodium acetate, potassium chloride $(\mathrm{KCl})$, metaphosphoric acid, iodine solution were of AOAC standard obtained from local vendor. Nitrate salt of metals were from Buck Scientific, USA; and riboflavin, thiamine, vitamin C standards, diastase enzyme were from Sigma, Aldrich.

Determination of mineral content: $1 \mathrm{~g}$ pulp sample was digested with $100 \mathrm{~mL}$ of $1 \mathrm{M} \mathrm{HNO}_{3}$. The digestion was heated for $2 \mathrm{hrs}$. The digested extracts were filtered and the filtrate made up to $50 \mathrm{~mL}$ with deionised water. The filtrates were analysed for sodium $(\mathrm{Na})$, potassium $(\mathrm{K})$, calcium $(\mathrm{Ca})$, iron $(\mathrm{Fe})$, phosphorus $(\mathrm{P})$, copper $(\mathrm{Cu})$, manganese $(\mathrm{Mn})$, and zinc $(\mathrm{Zn})$ using Atomic Absorption Spectrophotometer (AAS, Buck, 200 Model).

Determination of Thiamine (Vit. $B_{1}$ ): Fifty millilitres of $0.1 \mathrm{M} \mathrm{H}_{2} \mathrm{SO}_{4}$ was added to $1 \mathrm{~mL}$ of $10 \mathrm{~g}$ pulp and the mixture was mixed and $5 \mathrm{~mL}$ diastase / $0.5 \mathrm{M}$ sodium acetate solution/ ice was added and further kept in ice for $2 \mathrm{hr}$ and the digest was made up to 100 $\mathrm{mL}$ (Salvia-Trujillo et al., 2011). The resulting mixture was filtered through No.42 Whatmann filter paper and $10 \mathrm{~mL}$ upper layer was discarded. Five millilitre acidified potassium chloride solution was added to $10 \mathrm{~mL}$ filtrate and mixed, thoroughly. Serial dilutions of thiamine standards were prepared and their absorbance and that of samples were measure at $285 \mathrm{~nm}$ wavelength using a fluorescent UV spectrophotometer. The amount of thiamine in the 
samples was extrapolated from the derived calibration graph of absorbance measures.

Determination of Riboflavin (Vit $B_{2}$ ): Five millilitres of $5 \mathrm{M} \mathrm{HCl}$ was added to $1 \mathrm{~mL} 10 \mathrm{~g}$ pulp sample and followed by addition of $5 \mathrm{~mL}$ dichloroethene. The mixture was shaken, allowed to settle and made up to $100 \mathrm{~mL}$ with deionized water and heated in a steam bath for $30 \mathrm{~min}$. The mixture was cooled, made up to $100 \mathrm{~mL}$ with deionized water, filtered and decant 20 $\mathrm{mL}$ upper layer. Two millilitres of the filtrate was made up to $250 \mathrm{~mL}$ with deionized water and series of standard solutions of riboflavin were prepared. Absorbance of samples and standards were measured at $460 \mathrm{~nm}$ using a fluorescent UV spectrophotometer.

Determination of Ascorbic acid (Vit. C): Vitamin C in the $10 \mathrm{~g}$ pulp samples was determined using Iodometric titration by adding $10 \mathrm{~mL}$ metaphosphoric acid to $5 \mathrm{~mL}$ pulp extract samples, the mixture was then blended for $3 \mathrm{~min}$ and filtered, $20 \mathrm{~mL}$ filtrate was pipetted into a beaker and 3 drops of starch indicator was added and titrated against $0.1 \mathrm{M}$ iodine solution and a blue-black colour indicated the end point.

Data Management: Collected data was subjected to Statistical Analysis System University Edition 3 (SAS, 2019), and Z test using Excel sheet.

\section{RESULTS AND DISCUSSION}

General level of minerals and vitamins content of mango and contribution to dietary reference intake:

Table 1 provides the descriptive statistics of minerals and vitamins obtained in $100 \mathrm{~g} \mathrm{FW}$ mango fruit from Ijebu-Mamu and visual values indicate high level of $\mathrm{K}$ and Vit. C, appreciable quantity of $\mathrm{Ca}, \mathrm{P}$ and $\mathrm{Na}$, while other minerals and vitamins are low in quantity and $\mathrm{Zn}$ wasn't detected at all. Whatsoever, values obtained were considered for their contribution to DRI based on the RDA / Al needed for an individual to keep healthy and well-nourished as presented in Table 1.

Incomparably, the high level of K could only provide an average range value of 11.9 to $15.7 \% \mathrm{AI}$ across all age groups in 1 to 2 cup of mango ( 165 to $330 \mathrm{~g}$ ) while level of $\mathrm{Cu}$ could cater for 14.3 to $32.3 \% \mathrm{RDA} / \mathrm{AI}$ across age groups. Mango could contribute a proportion of 11 to $20 \%$ RDA Vit. $\mathrm{B}_{1}$ and 13 to $23 \%$ Vit. $B_{2}$. Only vitamin C content of Ijebu-Mamu mango suffices RDA across ages and even, surpasses in almost all age groups. Therefore, at present, less than one-third cup of mango ( $46 \mathrm{~g})$ and one-half cup (76.5 g) could cater for 15 and $25 \mathrm{mg} / \mathrm{d}$ Vit. C RDA for 1-3 y and 3-8 y children, respectively, one cup adequately takes care of $45 \mathrm{~g} / \mathrm{d}$ for teenagers, and one and a half cup provides somewhat greater than 100 RDA for the rest of age groups evaluated (Table 1). Nevertheless, the presence of these minerals and vitamins in the assessed mangoes of Ijebu-Mamu supports the findings that mango consumption was associated with better nutrient intakes and diet quality due to its high Vit $\mathrm{C}$, an antioxidant that scavenges reactive oxygen and low sodium content that prevents high blood pressure.

The range amount of minerals and vitamins detected at present in Ijebu Mamu mango is within diverse reported levels in literatures and the evaluated differences are attributes of geographical zones, varieties, maturity, ripening, agricultural practices, genetic, genetic by environment and post-harvest technology (Ara et al., 2014; Okoth et al., 2013; Shi et al., 2015; Sogi et al., 2012).

Effect of differential harvest / handling and postharvest conditions on minerals and vitamins content of mango: Table 2 shows level of Na, K, Ca, $\mathrm{Fe}, \mathrm{Mn}$ and Vitamins is higher when mango fruits are before-dropping while level of $\mathrm{P}$ and $\mathrm{Cu}$ is higher in after-dropping. This result indicates nutrition feeding of mangoes while on parent plants (PFAF, 2017) with perhaps simultaneous catabolic and anabolic processes that release and uptake specific minerals as cofactor during photosynthesis.

These processes are likely reduced or halt at after dropping from parent tree while some postharvest enzymatic and non-enzymatic processes were perhaps initiated such as Calvin cycle after light reactions and ATP hydrolysis to increase P (Berg et al., 2007).

Same Table 2 shows disparity in distribution of highest level of the assessed minerals and vitamins among the handling conditions with RMP having highest level of $\mathrm{Na}$ and $\mathrm{Ca}, \mathrm{R}_{2} \mathrm{MP}$ has highest level of Vit $\mathrm{B}_{1}, \mathrm{R}_{2} \mathrm{MPHR}$ has highest $\mathrm{Ca}, \mathrm{Mn}$ and $\mathrm{Vit} \mathrm{B}_{2}$, and UMP has highest level of Vit C. Noteworthy, mango is commonly harvested green while firm on parent plant and ripened with postharvest management (Kader and Mitcham, 2008). Therefore, the assessed handling conditions are somewhat nutrient-specific and worth evaluating for best harvest handlings practice in mango. Table 2 also shows ripe mango have highest level of minerals except $\mathrm{Fe}$, half-ripened mango presented highest level of vits. $\mathrm{B}_{1}$ and $\mathrm{B}_{2}$ and unripe mango have highest level of $\mathrm{Fe}$ and Vit. $\mathrm{C}$. 
Table 1: Descriptive statistics for level of minerals and vitamins in mango fruits from Ijebu-Mamu and their Daily food intake (DI) and contributions to Dietary Reference Intake (RDI)



SD, Standard deviation; Daily food intake (DI) and contributions to Dietary Reference Intake (RDI). Recommended Dietary Allowances (RDAs) are in ordinary text and Adequate Intakes (Als) are in bold text. The RDI reports is adapted from www.nap.edu

This suggests half-ripen mangoes have not received and heat caused released of more minerals due to their enough mineral nutrition on parent plant and ripening presence as co factor of enzymes for synthesis of MOYIB, OK; OMOTOLA, OE; BANJOKO, OO, EZIKE, BU 
organic substances and anabolism of key metabolites necessary for full ripening while $\mathrm{Vit} \mathrm{C}$ was very high in unripe mango and driven into simple sugars syntheses during ripening (Berg et al., 2007; Sogi et al., 2012; Kong and Singh, 2013). In corroboration, studies on quality of mangoes at different ripening stages have shown reducing Vit $\mathrm{C}$ with increasing ripening (Baloch and Bibi, 2012; Okoth et al., 2013; Wafula et al., 2015). Increased heat from ambient temperature $25 \pm 3^{\circ} \mathrm{C}, 80 \pm 11 \% \mathrm{RH}$ to $35 \pm 5^{\circ} \mathrm{C}, 55 \pm 70 \%$ $\mathrm{RH}$ caused increased level of minerals except $\mathrm{P}$, reduced level of vitamins and no impact on level of $\mathrm{Cu}$ (Table 2). Vitamins followed expected result as most heat labile substances while few minerals showed disparity according to their biological system requirement or bioavailability (Kramer, 1977). Studies have shown that heat increases cellular respiration that initiates and increases enzymatic reactions for breaking down of complex organic molecules to generate minerals, and also, using up some microminerals for syntheses of phytochemicals during ripening process and also heat treatments reduced fruit sensory quality, leading to loss of flavour and nutrient quality (Baloch and Bibi, 2012; Escribano and Mitcham, 2014; Yi et al.,, 2020). The minerals show increase in level from 0 dah to a peak at 4 or 6 dah except $\mathrm{Na}$ and $\mathrm{Mn}$ that increases till 10 and $8 \mathrm{DAH}$, respectively, while vitamins reduces from 0 till 10 dah (Table 2). The present results suggest releasing of minerals at shorter dah followed by their channelling into metabolic processes and perhaps with presence of microorganisms scavenging the nutrients for their metabolic processes at lengthy dah while the assessed vitamins undergone destructive oxidation (Kramer, 1977).

\begin{tabular}{|c|c|c|c|c|c|c|c|c|c|c|c|c|}
\hline Obs & $\begin{array}{l}\text { Harvest } \\
\text { Condition }\end{array}$ & Freq & $\mathrm{Na}$ & $\mathbf{K}$ & $\mathrm{Ca}$ & p & $\mathrm{Cu}$ & $\mathrm{Fe}$ & Mn & Vit C & Vit $B_{1}$ & Vit $B_{2}$ \\
\hline & Harvest & & & & & & & & & & & \\
\hline 1 & $\begin{array}{l}\text { Before } \\
\text { dropping }\end{array}$ & 90 & $4.39^{2}$ & $229.70^{2}$ & $24.10^{2}$ & $5.52^{b}$ & $0.05^{b}$ & $0.45^{2}$ & $0.061^{\mathrm{nn}}$ & $33.44^{\mathrm{nI}}$ & $0.05^{\mathrm{ma}}$ & $0.06^{\mathrm{ma}}$ \\
\hline \multirow[t]{2}{*}{2} & $\begin{array}{l}\text { After } \\
\text { dropping }\end{array}$ & 90 & $3.83^{b}$ & $221.04^{b}$ & $22.77^{\mathrm{b}}$ & $6.08^{2}$ & $0.06^{2}$ & $0.40^{\mathrm{b}}$ & 0.057 & 31.91 & 0.04 & 0.05 \\
\hline & Handling & & & & & & & & & & & \\
\hline 1 & RMP & 18 & $4.71^{2}$ & $234.46^{\text {b }}$ & $25.73^{2}$ & $5.82^{\text {abed }}$ & $0.050^{23}$ & $0.4^{b}$ & $0.052^{b s}$ & $33.00^{b s}$ & $0.062^{2 h}$ & $0.077=$ \\
\hline 2 & R2MP & 18 & $4.53^{2}$ & $234.04^{\text {the }}$ & $23.40^{\text {bed }}$ & $5.62^{\text {bed }}$ & $0.048^{b=}$ & $0.44^{\mathrm{b}}$ & $0.064^{2}$ & $34.68^{2 h}$ & $0.077^{2}$ & $0.062^{2 b c}$ \\
\hline 3 & R2MPHR & 18 & $4.63^{2}$ & $237.07^{2}$ & $24.51^{\text {h }}$ & $5.47^{\mathrm{ed}}$ & $0.045^{\mathrm{c}}$ & $0.45^{\mathrm{ab}}$ & $0.067^{2}$ & $30.26^{b s}$ & $0.042^{b e}$ & $0.080^{\circ}$ \\
\hline 4 & R2MGHR & 18 & $4.15^{b}$ & $228.58^{\mathrm{bed}}$ & $23.92^{b c}$ & $6.06^{\mathrm{abe}}$ & $0.063^{2}$ & $0.39^{=}$ & $0.066^{2}$ & $29.03^{e}$ & $0.041^{b e}$ & $0.029^{\circ}$ \\
\hline 5 & UMPHR & 18 & $4.09^{b}$ & $226.53^{\text {edr }}$ & $24.26^{\mathrm{bsc}}$ & $5.35^{\mathrm{d}}$ & $0.045^{\circ}$ & $0.48^{2}$ & $0.062^{\text {sh }}$ & $31.44^{b s}$ & $0.024^{e}$ & $0.042^{\text {edz }}$ \\
\hline 6 & $\mathrm{RMG}$ & 18 & $3.76^{=}$ & $223.73^{\text {sef }}$ & $23.91^{b=}$ & $6.32^{2}$ & $0.064^{2}$ & $0.34^{d}$ & $0.052^{\mathrm{be}}$ & $31.6^{\mathrm{be}}$ & $0.058^{2 b}$ & $0.068^{=b}$ \\
\hline 7 & UMP & 18 & $3.97^{\mathrm{be}}$ & $216.41^{\mathrm{fs}}$ & $22.61^{\text {edz }}$ & $5.36^{\mathrm{d}}$ & $0.045^{c}$ & $0.47^{2}$ & $0.048^{d}$ & $37.83^{2}$ & $0.041^{b e}$ & $0.054^{\text {bed }}$ \\
\hline 8 & R2MG & 18 & $3.88^{\mathrm{bc}}$ & $219.42^{\text {efs }}$ & $22.48^{\text {edz }}$ & $6.21^{\text {ab }}$ & $0.060^{2}$ & $0.38^{=}$ & $0.059^{23}$ & 32.88 & $0.047^{\mathrm{be}}$ & $0.031^{\epsilon}$ \\
\hline 9 & UMGHR & 18 & $3.72^{=}$ & $221.32^{\text {def }}$ & $22.11^{e}$ & $5.88^{\text {bbed }}$ & $0.056^{\text {b }}$ & $0.44^{b}$ & $0.059^{2 b}$ & $30.85^{b s}$ & $0.034^{e}$ & $0.069^{=b}$ \\
\hline \multirow[t]{2}{*}{10} & UMG & 18 & $3.67^{=}$ & $212.15^{5}$ & $21.44^{\mathrm{d} z}$ & $5.92^{\text {abed }}$ & $0.047^{\circ}$ & $0.43^{b}$ & $0.051^{\mathrm{be}}$ & $35.19^{2 / 2}$ & $0.042^{b e}$ & $0.039^{d=}$ \\
\hline & Ripe & & & & & & & & & & & \\
\hline 1 & Half-Ripen & 48 & $4.10^{2}$ & $225.76^{2}$ & $23.32^{2}$ & $5.76^{b}$ & $0.05^{b}$ & $0.44^{2}$ & $0.055^{b}$ & $36.15^{6}$ & $0.07^{2}$ & $0.08^{2}$ \\
\hline 2 & Ripe & 101 & $4.38^{\mathrm{b}}$ & $230.13^{2}$ & $24.21^{2}$ & $6.11^{2}$ & $0.06^{2}$ & $0.40^{b}$ & $0.065^{\circ}$ & $28.57^{\circ}$ & $0.04^{b}$ & $0.04^{=}$ \\
\hline \multirow[t]{2}{*}{3} & Unripe & 31 & $3.26^{=}$ & $209.27^{\mathrm{b}}$ & $21.09^{\circ}$ & $4.84^{=}$ & $0.04^{=}$ & $0.46^{2}$ & $0.040^{\circ}$ & $40.67^{2}$ & $0.06^{\mathrm{zb}}$ & $0.06^{\mathrm{b}}$ \\
\hline & Heat & & & & & & & & & & & \\
\hline 1 & $25 \pm 3^{\circ} \mathrm{C}$ & 107 & $4.08^{\mathrm{ma}}$ & $223.46^{b}$ & $23.27^{n x}$ & $5.88^{\mathrm{m}}$ & $0.05^{\mathrm{ma}}$ & $0.41^{b}$ & $0.05^{b}$ & $34.22^{2}$ & $0.059^{2}$ & $0.064^{2}$ \\
\hline \multirow[t]{2}{*}{2} & $35 \pm 5^{\circ} \mathrm{C}$ & 73 & 4.16 & $228.17^{2}$ & 23.69 & 5.69 & 0.05 & $0.43^{2}$ & $0.06^{2}$ & $30.41^{b}$ & $0.035^{b}$ & $0.044^{b}$ \\
\hline & DAH & & & & & & & & & & & \\
\hline 1 & 0 & 30 & $3.62^{2}$ & $211.59^{=}$ & $20.02^{d}$ & $4.74^{d}$ & $0.036^{d}$ & $0.39^{d}$ & $0.037^{e}$ & $42.38^{2}$ & $0.09^{2}$ & $0.09^{2}$ \\
\hline 2 & 2 & 30 & $3.87^{\mathrm{be}}$ & $221.09^{b}$ & $22.65^{\mathrm{c}}$ & $5.46^{2}$ & $0.045^{c}$ & $0.44^{\mathrm{be}}$ & $0.050^{d}$ & $38.06^{\circ}$ & $0.07^{\mathrm{ab}}$ & $0.08^{b}$ \\
\hline 3 & 4 & 30 & $4.07^{b}$ & $231.85^{2}$ & $26.28^{2}$ & $6.36^{\mathrm{b}}$ & $0.055^{b}$ & $0.49^{2}$ & $0.059^{\circ}$ & $33.83^{e}$ & $0.05^{b}$ & $0.07^{=}$ \\
\hline 4 & 6 & 30 & $4.35^{2}$ & $236.42^{2}$ & $25.53^{2}$ & $6.65^{2}$ & $0.063^{2}$ & $0.46^{b}$ & $0.068^{b}$ & $30.48^{d}$ & $0.05^{b}$ & $0.05^{\mathrm{d}}$ \\
\hline 5 & 8 & 30 & $4.36^{2}$ & $231.94^{2}$ & $23.99^{6}$ & $6.28^{\mathrm{b}}$ & $0.062^{2}$ & $0.42^{=}$ & $0.076^{\circ}$ & $27.19^{=}$ & $0.02^{=}$ & $0.03=$ \\
\hline 6 & 10 & 30 & $4.39^{2}$ & $219.33^{\mathrm{b}}$ & $22.15^{\mathrm{e}}$ & $5.31^{=}$ & $0.052^{b}$ & $0.35^{=}$ & $0.065^{b}$ & $24.13^{i}$ & $0.01^{=}$ & $0.02=$ \\
\hline
\end{tabular}

Increases level of Na suggests its reduced or zero used as a cofactor or by microbes. The present results support the findings that mangoes shell life varies from 4 to 14 days at ambient temperature (Herianus et al., 2003) but not with only loss of sensory, flavour, texture, and macronutrient quality during lengthy storage days, of which Vit. C is a major marker (Baloch and Bibi, 2012; Escribano and Mitcham, 2014), in addition, minerals and vitamins such as $\mathrm{Na}$, $\mathrm{K}, \mathrm{Ca}, \mathrm{P}, \mathrm{Fe}, \mathrm{Cu}, \mathrm{Mn}, \mathrm{Vit} \mathrm{B}_{1}$ and $\mathrm{B}_{2}$, are also significantly lost and they could also serve as added markers for nutrient quality over storage dah in 
mangoes. General linear model ANOVA statistics denotes if the level of the minerals and vitamins observed in Table 2 are significantly different or not among the various assessed harvest handling and postharvest conditions and the observed significant differences are visually signified on their means in Table 2.

There is a clear cut demarcation of means between the two harvests for $\mathrm{Na}, \mathrm{K}, \mathrm{Ca}, \mathrm{P}, \mathrm{Cu}$ and $\mathrm{Fe}$, while $\mathrm{Mn}$, Vits. $\mathrm{C}, \mathrm{B}_{1}$ and $\mathrm{B}_{2}$ are not significantly different, translating to good nutrition on parent plant is significant. The differences in the level of minerals and vitamins observed among the various handling evaluated are highly significant as depicted in Table 2 . Level of minerals and vitamins are also significant among the three ripening status while $\mathrm{K}$ and $\mathrm{Ca}$ are not significantly different between half-ripe and ripe. On a close observation at Table $2, \mathrm{~K}, \mathrm{Fe}, \mathrm{Mn}$ and vitamins are the only significantly different nutrients for heat, other differences observed in Table 2 are not significant. Conspicuously, levels of nutrients are highly significant for diverse assessed DAH with Vit. $\mathrm{C}$ presents distinct significant differences among the DAH. Related studies have reported significant differences of nutritional, organoleptic and functional properties in mangoes at diverse pre and post-harvest conditions but scantily on minerals and vitamins at harvest handling (Baloch and Bibi, 2012; Lee and Kader, 2000; Kong and Singh, 2013; Normand et al., 2015; Shi et al., 2015; Wafula, et al., 2015). Therefore, the significant differences highlighted at present are useful for nutritious mango at both harvest handling and postharvest management and detailed descriptive ANOVA statistics is available on request. Before dropping, hand-plucked on parent plants; after dropping, hand-picked on the ground around parent plants; RMP, ripe mango on plant; $\mathrm{R}_{2} \mathrm{MP}$, half-ripen mango on plant; $\mathrm{R}_{2} \mathrm{MPHR}$, heat ripened- half-ripen mango on plant; UMP, unripe mango on plant; UMPHR, heat ripened- unripe mango on plant; RMG, ripe mango after dropping on ground; $\mathrm{R}_{2} \mathrm{MG}$, halfripen mango on ground; $\mathrm{R}_{2} \mathrm{MGHR}$, heat ripened-halfripen mango on ground; UMG, unripe mango on ground; UMGHR, heat ripened- unripe mango on ground. DAH, day after harvest.

Interaction effects and correlations among harvest, ripe, heat, and dah on Minerals and Vitamins in mango: Noticeably, there is high significant interactions of the harvest and postharvest conditions on the level of minerals and vitamins assessed and only interactions for harvest, ripe, heat and DAH are presented to avoid very large Table 3 (Detailed ANOVA statistics available on request). Table 3 also presents the direction of impact observed for heat, ripe and storage dah on the assessed minerals and vitamins (handling was omitted due to its cumbersome quantitation).

The only significant relationships among the assessed harvest and postharvest conditions is the positive correlation between ripe and dah, that is, ripening increases with dah. The macro minerals and $\mathrm{Fe}$ showed weak positive relationships with harvest while $\mathrm{P}$ and $\mathrm{Cu}$ showed reverse relationship but $\mathrm{Mn}$ and vitamins displayed no relationship. The minerals moderately increase with ripening while $\mathrm{Fe}$ and vitamins weakly decrease but Vit $\mathrm{C}$ shows a strong inverse relationship. Only level of $\mathrm{K}, \mathrm{Fe}, \mathrm{Cu}$ and $\mathrm{Mn}$ showed weak increase with increasing heat among the minerals while level of vitamins weakly declined with heat. Minerals increase with increasing dah except Fe that shows a weak inverse relationship and vitamins strongly decrease with increasing dah. The correlation relationships show the effect of the harvest handling and postharvest conditions do not possesses a tidy or regular direction with one another and for some minerals and vitamins. The minerals and vitamins show positive relationship with one another with strongest association among $\mathrm{Na}, \mathrm{K}$, and $\mathrm{Ca} ; \mathrm{Mn}$ and Vit $\mathrm{C}$; Vit $\mathrm{C}$ and Vit $\mathrm{B}_{1}$; and Vit $\mathrm{B}_{1}$ and $\mathrm{B}_{2}$. Interaction effects of heat, time and ripe on flavour, nutrient quality and taste have been previously reported and are usually useful for optimizing conditions necessary for postharvest management of mango. In sequel, optimal temperature*time combination has been emphasized as a key factor but more is on Vit C, sugar content, texture, phenolic compounds, organic acids and microorganism attack ((Lee and Kader, 2000; Baloch and Bibi, 2012; Herianus et al., 2003; Joshi et al., 2017) but scantly on minerals and vitamins, which is necessary considering mineral malnutrition ravaging underdeveloped countries. The present results highlight the importance of the co-effects of the present assessed harvest handling and postharvest conditions and their co-optimization that might be necessary for maximizing minerals and vitamins in mango for end use and consumer quality acceptance, though, require further researches. The present reported relationships are useful in breeding or fortifying mango for good nutrition and such useful relationships has been reported for antioxidants, minerals and orange colour in mango (Shi et al., 2015; Yusuf et al., 2018). Selection of optimal integrated harvest and postharvest condition for high level of minerals and vitamins in mango: One tailed $\mathrm{z}$ test was carried out to assess best and worst integrated harvest condition for high level of minerals and vitamins that could be used to obtain a nutritious mango and Table 4 shows $\rho$ values in green and blue colour as the highest and lowest nutrient content, respectively. 
Table 3: Analysis of variance and Pearson Correlations statistics for interaction effects among harvest, ripe, heat and time on minerals and vitamins content of mango fruit

\begin{tabular}{|c|c|c|c|c|c|c|c|c|c|c|c|c|c|c|}
\hline \multirow{3}{*}{ Nutrient } & \multicolumn{8}{|c|}{ Harvest Interactions } & \multicolumn{6}{|c|}{ Ripe heat*Dah interactions } \\
\hline & \multicolumn{2}{|c|}{$\begin{array}{l}\text { Model } \\
\text { statistics }\end{array}$} & \multirow{2}{*}{$\begin{array}{l}\text { Harvest } \\
\text { *Ripe } \\
\text { Pr }>F^{\beta}\end{array}$} & \multirow{2}{*}{$\begin{array}{l}\text { Harvest* } \\
\text { Heat } \\
\text { Pr> } F^{\beta}\end{array}$} & \multirow{2}{*}{$\begin{array}{l}\text { Harvest } \\
\text { *Dah } \\
\text { Pr>F }\end{array}$} & \multirow{2}{*}{$\begin{array}{l}\text { Harvest* } \\
\text { Ripe*Hea } \\
\text { t } \\
\text { Pr>F }\end{array}$} & \multirow{2}{*}{$\begin{array}{l}\text { Harve } \\
\text { st* } \\
\text { Heat* } \\
\text { Dah } \\
\text { Pr }>F^{\beta}\end{array}$} & \multirow{2}{*}{$\begin{array}{l}\text { Harvest*R } \\
\text { ipe* } \\
\text { heat*Dah } \\
\text { Pr>F }\end{array}$} & \multicolumn{2}{|c|}{ Model statistics } & \multirow{2}{*}{$\begin{array}{l}\text { Ripe*Hea } \\
t\end{array}$} & \multirow{2}{*}{$\begin{array}{l}\text { Ripe*dah } \\
\operatorname{Pr}>F^{\beta}\end{array}$} & \multirow{2}{*}{$\begin{array}{l}\text { Heat*dah } \\
\text { Pr }>\mathrm{F}\end{array}$} & \multirow{2}{*}{$\begin{array}{l}\text { Ripe* } \\
\text { Heat* } \\
\text { dah } \\
\text { Pr>F }\end{array}$} \\
\hline & $\mathrm{R}^{2}$ & $\mathrm{CV}$ & & & & & & & $\overline{R^{2}}$ & $\mathrm{CV}$ & & & & \\
\hline $\mathbf{N a}$ & 0.86 & 5.35 & **** & $* * *$ & **** & $* * *$ & $* * *$ & $* * *$ & 0.63 & 8.97 & **** & $* * *$ & $* * *$ & $* * *$ \\
\hline $\mathbf{K}$ & 0.84 & 2.5 & $* * *$ & $* * *$ & $* * *$ & $* * *$ & $* * *$ & $* * *$ & 0.79 & 2.86 & $* * *$ & $* * *$ & $* * *$ & $* * *$ \\
\hline $\mathbf{C a}$ & 0.91 & 3,5 & $* * *$ & $* * *$ & $* * *$ & $* * *$ & $* * *$ & $* * *$ & 0.85 & 4.73 & $* * *$ & $* * *$ & $* * *$ & $* * *$ \\
\hline $\mathbf{P}$ & 0.89 & 5.2 & $* * *$ & $* * *$ & $* * *$ & $* * *$ & $* * *$ & $* * *$ & 0.81 & 6.97 & $* * *$ & $* * *$ & $* * *$ & $* * *$ \\
\hline $\mathrm{Cu}$ & 0.78 & 12.9 & $* * *$ & $* * *$ & $* * *$ & $* * *$ & $* * *$ & $* * *$ & 0.64 & 16.8 & $* * *$ & $* * *$ & $* * *$ & $* * *$ \\
\hline $\mathbf{F e}$ & 0.89 & 5.02 & $* * *$ & $* * *$ & $* * *$ & $* * *$ & $* * *$ & $* * *$ & 0.72 & 8.2 & $* * *$ & $* * *$ & $* * *$ & $* * *$ \\
\hline Mn & 0.80 & 13.0 & $* * *$ & $* * *$ & $* * *$ & $* * *$ & $* * *$ & $* * *$ & 0.79 & 13.4 & $* * *$ & $* * *$ & $* * *$ & $* * *$ \\
\hline Vit. C & 0.94 & 5.51 & $* * *$ & $* * *$ & $* * *$ & $* * *$ & $* * *$ & $* * *$ & 0.94 & 5.54 & $* * *$ & $* * *$ & $* * *$ & $* * *$ \\
\hline Vit $B_{1}$ & 0.46 & 25.2 & $*$ & $* * *$ & $* * *$ & $* * *$ & $* * *$ & $* * *$ & 0.88 & 25.4 & $* * *$ & $* * *$ & $* * *$ & $* * *$ \\
\hline \multirow[t]{3}{*}{ Vit $\mathbf{B}_{2}$} & 0.86 & 23.4 & $* * *$ & $* * *$ & $* * *$ & $* * *$ & $* * *$ & $* * *$ & 0.84 & 26.4 & $* * *$ & $* * *$ & $* * *$ & $* * *$ \\
\hline & \multicolumn{13}{|c|}{ Pearson Correlation among assessed harvest and postharvest conditions, and nutrients } & \\
\hline & Ripe & Heat & Dah & $\mathrm{Na}$ & $\mathbf{K}$ & $\mathbf{C a}$ & $\mathbf{P}$ & $\mathbf{C u}$ & $\mathrm{Fe}$ & Mn & Vit. C & Vit. $B_{1}$ & Vit $\mathbf{B}_{2}$ & \\
\hline Harvest $^{\dagger}$ & NS & NS & NS & $-0.5^{* * *}$ & $-0.33^{* * * *}$ & $-0.25^{* * *}$ & $0.32^{* * *}$ & $0.42^{* * *}$ & $-0.43^{* * *}$ & NS & NS & NS & NS & \\
\hline Ripe $^{\ddagger}$ & & NS & $0.64^{* * *}$ & $0.69^{* * *}$ & $0.54^{* *}$ & $0.43^{*}$ & $0.52^{*}$ & $0.60^{* * *}$ & $-0.42^{* * *}$ & $0.57^{* * *}$ & $0.70 *$ & $-0.2^{*}$ & $-0.26^{* * *}$ & \\
\hline Heat & & & NS & & $0.18^{*}$ & $0.15^{*}$ & NS & NS & $0.19^{*}$ & $0.28^{* * * * *}$ & $-0.26^{* * *}$ & $-0.25^{* *}$ & $0.29^{* * * *}$ & \\
\hline $\operatorname{Dah}^{\delta}$ & & & & $0.49^{* * *}$ & $0.29^{* * *}$ & $0.27^{* * * *}$ & $0.32^{* * *}$ & $0.51^{* * * *}$ & $-0.23^{* *}$ & $0.72^{* * *}$ & $-0.90^{* * * *}$ & $-0.55^{* * *}$ & $-0.80^{* * *}$ & \\
\hline $\mathrm{Na}$ & & & & & $0.75^{* * *}$ & $0.56^{* * *}$ & $0.36^{* * *}$ & $0.31^{* * *}$ & $\mathrm{~ns}$ & $0.59^{* * *}$ & $-0.52^{* * *}$ & $\mathrm{~ns}$ & $-0.19^{*}$ & \\
\hline $\mathrm{K}$ & & & & & & $0.81^{* * *}$ & $0.59^{* * *}$ & $0.49^{* * *}$ & $0.34^{* * *}$ & $0.60^{* * *}$ & $-0.45^{* * *}$ & $\mathrm{~ns}$ & $\mathrm{~ns}$ & \\
\hline $\mathrm{Ca}$ & & & & & & & $0.66^{* * *}$ & $0.51^{* * * *}$ & $0.47^{* * * *}$ & $0.53^{*}$ & $0.41^{* * *}$ & ns & $\mathrm{ns}$ & \\
\hline $\mathrm{P}$ & & & & & & & & $0.81^{* * * *}$ & $0.19^{*}$ & $0.50^{* * * *}$ & $-0.39^{* * *}$ & ns & $-0.16^{*}$ & \\
\hline $\mathrm{Cu}$ & & & & & & & & & NS & $0.59^{* * *}$ & $-0.60^{* * * *}$ & $-0.24^{* *}$ & $-0.30^{* * *}$ & \\
\hline $\mathrm{Fe}$ & & & & & & & & & & NS & NS & NS & & \\
\hline $\mathrm{Mn}$ & & & & & & & & & & & $-0.79^{* * *}$ & $-0.42^{* * *}$ & $-0.55^{* * *}$ & \\
\hline Vit. C & & & & & & & & & & & & $0.52^{* * * *}$ & $0.72^{* * * *}$ & \\
\hline Vit. $B_{1}$ & & & & & & & & & & & & & $0.64^{* * *}$ & \\
\hline
\end{tabular}

$\dagger$ Harvest- Before dropping $\rightarrow$ After dropping from parent plant; $\not$ Ripe - unripe $\rightarrow$ half ripe $\rightarrow$ ripe mango; $\square$ Heat $-25 \pm 3^{\circ} \mathrm{C} \rightarrow 35 \pm 5^{\circ} \mathrm{C} ;{ }^{\delta}$ Dah $-0 \rightarrow 10$ days; $*$ significant at $\rho ; 0.05 ; * *, \rho \leq 0.005$; $* * *, \rho \leq 0,0005 ; N S=$ not significant at $\rho=0$

Sixty-eight integrated harvest handling and postharvest conditions are generated but only best and worst 20 are presented and listed in the order of decreasing mean $\mathrm{p}$ values which is a representation of nutrient quality (full Table is available on request). Table 4 shows no single integrated harvest and postharvest condition has a complete $\mathrm{p}$ score of either 1.00 or 0.00 for all the minerals and vitamins assessed, signifying integrated harvest condition used could be nutrient specific as indicated for harvest handling and those showing high nutrient values among the best 20 listed are more desirable. The general linear model showed very high significant variation of mean $\rho$ scores among the integrated harvest condition $(\mathrm{r}=0.73, \mathrm{CV}=18.15, \mathrm{RMSE}=0.069$, and mean $=0.11, \mathrm{SS} 3=0.66, \mathrm{MS}=0.02, \rho<0.0001)$. Figure 1 is a Duncan grouping for visual separation of means and shows naturally ripened half-ripe mango on parent plant at 6 dah, $\mathrm{R}_{2} \mathrm{MPRHn} 6^{\mathrm{a}}$; ripe mango on parent plant at 4 dah, $\mathrm{RMPHn}^{\mathrm{ab}}$ and half-ripe mango on parent plant at $4 \mathrm{dah}, \mathrm{R}_{2} \mathrm{MPHn}^{\mathrm{ab}}$ as best three optimal integrated harvest conditions with no significant difference between RMPHn4 and $\mathrm{R}_{2}$ MPHn4. 
Table 4: $\mathrm{Z}$ test probability values for Integrated handling conditions for minerals and vitamins retention in mango fruits

\begin{tabular}{|c|c|c|c|c|c|c|c|c|c|c|c|c|c|}
\hline Obs & $\begin{array}{l}\text { Integrated } \\
\text { Harvest }\end{array}$ & Freq & $\mathbf{N a}$ & $\mathbf{K}$ & $\mathbf{C a}$ & p & $\mathrm{Cu}$ & $\mathbf{F e}$ & Mn & Vit C & VitB $_{1}$ & VitB $_{2}$ & $\begin{array}{l}\text { Mean } \\
\text { p }\end{array}$ \\
\hline 1 & R2MPHn6 & 1 & 1.00 & 1.00 & 1.00 & 1.00 & 1.00 & 1.00 & 0.98 & 0.71 & 0.85 & 1.00 & 0.95 \\
\hline 2 & RMPHn4 & 3 & 1.00 & 1.00 & 1.00 & 1.00 & 1.00 & 1.00 & 0.31 & 0.74 & 1.00 & 1.00 & 0.90 \\
\hline 3 & R2MPHn4 & 3 & 1.00 & 1.00 & 1.00 & 1.00 & 0.00 & 1.00 & 0.95 & 1.00 & 1.00 & 1.00 & 0.90 \\
\hline 4 & R2MGHRR4 & 2 & 0.71 & 1.00 & 1.00 & 1.00 & 1.00 & 1.00 & 0.93 & 0.07 & 0.78 & 0.99 & 0.85 \\
\hline 5 & RMGHn4 & 3 & 0.82 & 1.00 & 1.00 & 1.00 & 1.00 & 0.00 & 0.31 & 0.90 & 1.00 & 1.00 & 0.80 \\
\hline 6 & RMPHn6 & 3 & 1.00 & 1.00 & 1.00 & 1.00 & 1.00 & 1.00 & 0.93 & 0.00 & 0.71 & 0.33 & 0.80 \\
\hline 7 & R2MPHR2 & 3 & 1.00 & 0.99 & 1.00 & 0.00 & 0.00 & 1.00 & 0.93 & 1.00 & 1.00 & 1.00 & 0.79 \\
\hline 8 & R2MGHR4 & 1 & 0.88 & 1.00 & 1.00 & 1.00 & 1.00 & 1.00 & 0.93 & 0.08 & 0.01 & 0.98 & 0.79 \\
\hline 9 & RMPHn2 & 3 & 1.00 & 1.00 & 1.00 & 1.00 & 0.00 & 0.78 & 0.00 & 1.00 & 1.00 & 1.00 & 0.78 \\
\hline 10 & R2MPHRR6 & 3 & 1.00 & 1.00 & 1.00 & 1.00 & 1.00 & 1.00 & 1.00 & 0.00 & 0.00 & 0.66 & 0.77 \\
\hline 11 & UMPRHn8 & 2 & 1.00 & 0.99 & 1.00 & 1.00 & 1.00 & 1.00 & 0.46 & 0.96 & 0.00 & 0.00 & 0.74 \\
\hline 12 & R2MPRHn8 & 3 & 1.00 & 1.00 & 1.00 & 1.00 & 1.00 & 0.79 & 1.00 & 0.00 & 0.57 & 0.01 & 0.74 \\
\hline 13 & UMPHR8 & 3 & 1.00 & 1.00 & 1.00 & 1.00 & 1.00 & 1.00 & 1.00 & 0.00 & 0.00 & 0.00 & 0.70 \\
\hline 14 & R2MPHR4 & 3 & 1.00 & 1.00 & 1.00 & 1.00 & 0.00 & 1.00 & 1.00 & 0.00 & 0.00 & 0.67 & 0.67 \\
\hline 15 & R2MPHn2 & 3 & 1.00 & 1.00 & 0.00 & 0.00 & 0.00 & 1.00 & 0.62 & 1.00 & 1.00 & 1.00 & 0.66 \\
\hline 16 & RMGHn2 & 3 & 0.04 & 0.91 & 0.67 & 1.00 & 1.00 & 0.00 & 0.00 & 1.00 & 1.00 & 1.00 & 0.66 \\
\hline 17 & R2MGHn4 & 3 & 0.00 & 0.43 & 0.30 & 1.00 & 1.00 & 1.00 & 0.00 & 1.00 & 0.85 & 1.00 & 0.66 \\
\hline 18 & RMGHn6 & 3 & 0.53 & 1.00 & 1.00 & 1.00 & 1.00 & 0.00 & 0.98 & 0.00 & 0.38 & 0.66 & 0.65 \\
\hline 19 & R2MGHRR6 & 3 & 0.99 & 1.00 & 1.00 & 1.00 & 1.00 & 0.38 & 1.00 & 0.00 & 0.00 & 0.00 & 0.64 \\
\hline 20 & UMGHR/6 & 2 & 0.24 & 1.00 & 1.00 & 1.00 & 1.00 & 1.00 & 1.00 & 0.00 & 0.00 & 0.00 & 0.62 \\
\hline 21 & RMGHn8 & 3 & 0.00 & 0.00 & 0.67 & 1.00 & 1.00 & 0.00 & 0.95 & 0.00 & 0.00 & 0.00 & 0.36 \\
\hline 22 & UMPURHn2 & 3 & 0.00 & 0.00 & 0.00 & 0.00 & 0.00 & 1.00 & 0.00 & 1.00 & 0.85 & 0.66 & 0.35 \\
\hline 23 & UMPURHn0 & 3 & 0.00 & 0.00 & 0.00 & 0.00 & 0.00 & 0.79 & 0.00 & 1.00 & 0.71 & 0.99 & 0.35 \\
\hline 24 & UMPRHn10 & 2 & 1.00 & 0.00 & 0.00 & 0.24 & 1.00 & 0.00 & 0.96 & 0.09 & 0.00 & 0.00 & 0.33 \\
\hline 25 & R2MPHR10 & 3 & 1.00 & 1.00 & 0.32 & 0.00 & 0.00 & 0.00 & 0.95 & 0.00 & 0.00 & 0.00 & 0.33 \\
\hline 26 & UMGRHn8 & 3 & 0.43 & 0.02 & 0.00 & 1.00 & 0.00 & 0.78 & 1.00 & 0.01 & 0.00 & 0.00 & 0.32 \\
\hline 27 & RMGHn0 & 3 & 0.00 & 0.00 & 0.00 & 0.20 & 0.00 & 0.00 & 0.00 & 1.00 & 1.00 & 1.00 & 0.32 \\
\hline 28 & UMGHRUR2 & 3 & 0.00 & 0.00 & 0.00 & 0.00 & 0.00 & 1.00 & 0.00 & 1.00 & 0.85 & 0.33 & 0.32 \\
\hline 29 & UMPR10 & 1 & 1.00 & 0.00 & 0.00 & 0.17 & 1.00 & 0.01 & 0.93 & 0.05 & 0.00 & 0.00 & 0.32 \\
\hline 30 & R2MGHR0 & 3 & 0.00 & 0.00 & 0.00 & 0.00 & 0.00 & 0.00 & 0.00 & 1.00 & 1.00 & 1.00 & 0.30 \\
\hline 31 & R2MGHn0 & 3 & 0.00 & 0.00 & 0.00 & 0.00 & 0.00 & 0.00 & 0.00 & 1.00 & 1.00 & 1.00 & 0.30 \\
\hline 32 & UMGHRUR0 & 3 & 0.00 & 0.00 & 0.00 & 0.00 & 0.00 & 0.00 & 0.00 & 1.00 & 1.00 & 0.98 & 0.30 \\
\hline 33 & UMGURHn0 & 3 & 0.00 & 0.00 & 0.00 & 0.00 & 0.00 & 0.00 & 0.00 & 1.00 & 1.00 & 0.98 & 0.30 \\
\hline 34 & R2MGRHn10 & 3 & 0.25 & 0.00 & 0.00 & 0.50 & 1.00 & 0.00 & 0.98 & 0.00 & 0.00 & 0.00 & 0.27 \\
\hline 35 & UMGHR10 & 3 & 1.00 & 0.04 & 0.00 & 0.15 & 0.33 & 0.00 & 1.00 & 0.00 & 0.00 & 0.00 & 0.25 \\
\hline 36 & UMPHRUR2 & 3 & 0.00 & 0.00 & 0.04 & 0.00 & 0.00 & 1.00 & 0.00 & 1.00 & 0.01 & 0.00 & 0.20 \\
\hline 37 & R2MPRHn10 & 3 & 1.00 & 0.00 & 0.00 & 0.00 & 0.00 & 0.00 & 1.00 & 0.00 & 0.00 & 0.00 & 0.20 \\
\hline 38 & UMGRHn10 & 3 & 1.00 & 0.00 & 0.00 & 1.00 & 0.00 & 0.00 & 0.00 & 0.00 & 0.00 & 0.00 & 0.20 \\
\hline 39 & RMGHn10 & 3 & 0.00 & 0.00 & 0.00 & 0.00 & 1.00 & 0.00 & 0.31 & 0.00 & 0.00 & 0.00 & 0.13 \\
\hline 40 & RMPHn10 & 3 & 1.00 & 0.00 & 0.00 & 0.00 & 0.00 & 0.00 & 0.31 & 0.00 & 0.00 & 0.00 & 0.13 \\
\hline
\end{tabular}

$\delta$ integrated harvest acronyms for names are such that harvest and postharvest conditions are merged, examples, $2 M P H n 6$ is for half ripe mango on plant no heat at $6 \mathrm{DAH} ; \mathrm{RMGHn} 4$, ripe mango on ground no heat at $4 \mathrm{DAH}$; UMPHR8, unripe mango on plant heat ripened at 8 DAH; R2MGRHn10, half ripe mango ripe with no heat at $10 \mathrm{DAH}$;.Values in green and blue colors are best and worst scores, respectively. $P$ mean is the mean score of one tailed z test probability scores. When sample value is greater than population mean, $z$ test returns probability score greater than $0.5 . x>x$, then $p>0.5$.

The worst three integrated harvest are ripe mango on ground 10 dah, RMGHn10; ripe mango on parent plant at 10 dah, RMPHn10 and heat ripened mango on ground at 10 dah, UMGRHn10, with no significant difference between RMGHn10 and RMPHn10.

Close observations at Table 4 and Figure 1 reveal harvesting healthy mango as full ripen either plucked on parent tree or picked on ground and stored at 2 to 4 dah without heat, half ripened mango plucked on parent tree and stored to ripe between 4 to 6 dah without heat have highest mineral and vitamins content with few exceptions while harvesting mango irrespective of harvest handling and stored with or without heat at lengthy 8 to 10 dah and unripe mangos at 0 to 2 dah present worst minerals and vitamins content with few exceptions. This further confirms loss of nutrient quality with lengthy dah and also unripe mango is inferior in nutrient quality to ripe mangoes (Baloch and Bibi, 2012; Joshi et al., 2017; Herianus et al., 2003; Lee and Kader, 2000). The Correlation, Duncan grouping, GLM, and z-test analyses approach used at present enables selection of optimal harvest and postharvest conditions for high level of minerals and vitamins for a nutritious mango and have been previously used in mango for discriminating maturity, ripening, color and genotypes (Shi et al., 2015; Yusuf et al., 2018).

Same have been applied in beans, cassava, mushroom for crop improvement (Moyib et al., 2015a; Moyib et al., 2015b; Moyib et al., 2019). 


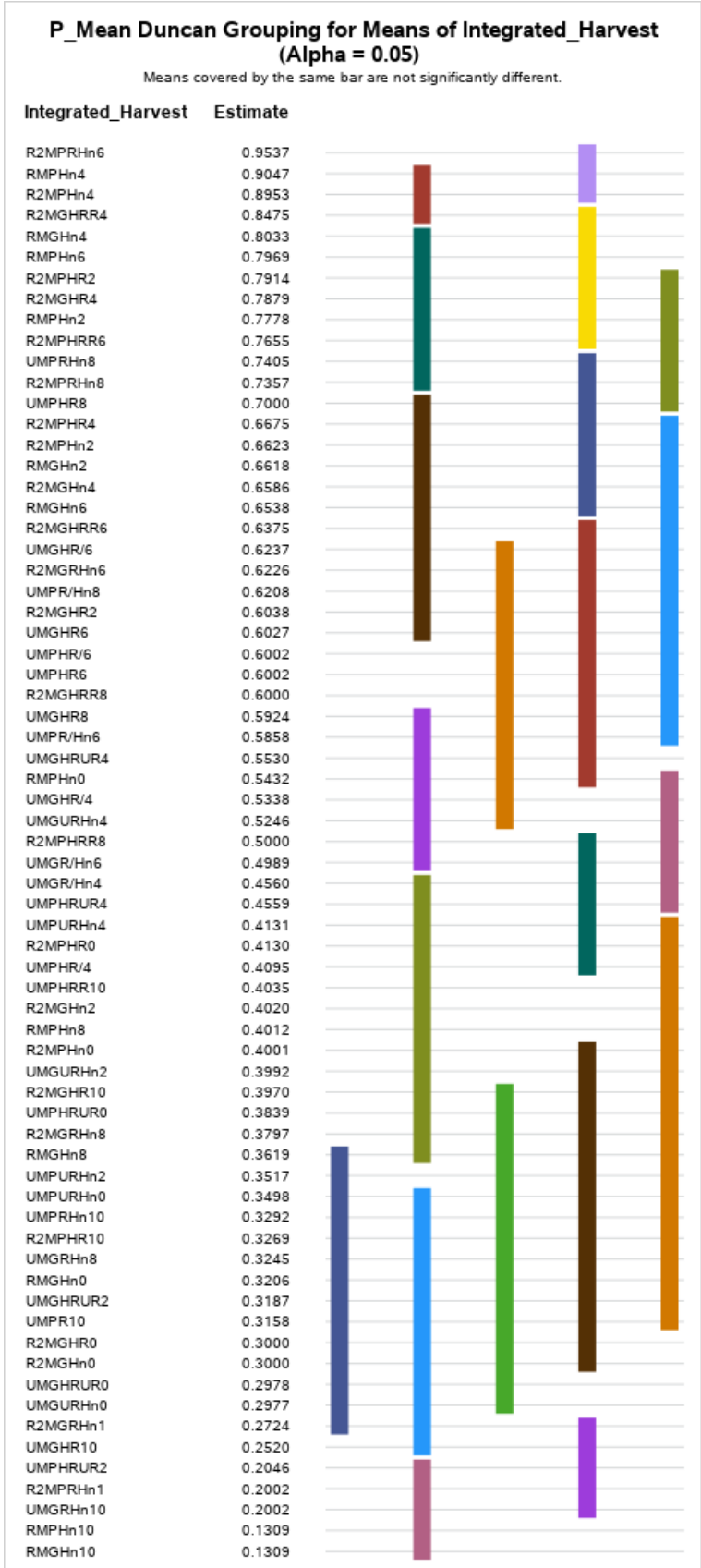

Fig 1. Duncan multiple grouping of combo pre and post-harvest handling conditions of mango fruits for retention of minerals and vitamins. Means that are not significantly different at $\mathrm{P}=0.05$ are covered by same colored bar. $\mathrm{P} \_$mean is the means of one tailed- $\mathrm{Z}$ test probability score returns, mean p. Integrated Harvest name acronyms are a combinatory of harvest handling and postharvest conditions acronyms.

Conclusion: Harvesting ripe mango on parent plant is nutritious while lengthy dah is adverse on its mineral and vitamin content. Unripe mangoes are poor nutrient and therefore, are not suitable when nutritious mango with high minerals and vitamins is the main focus. There is high interaction effect of various assessed harvest handling and postharvest condition on mineral and vitamin content of mango which might necessitates their co-optimization to maximize high nutrient level.

Acknowledgement: Our appreciation goes to IjebuMamu farmers' association for harvesting of mango samples and. SAS technical support team, South Africa, for guidance to the use of SAS University Edition 3.

\section{REFERENCES}

Ahmed, OK; Ahmed, S (2014). Determination of optimum maturity index of mango fruits (Mangifera indica, L.) in Darfur. ABJNA, 5(2): 97-103

Ara, R; Motalab, M; Uddin, MN; Fakhruddin, ANM; Saha, BK (2014). Nutritional evaluation of different mango varieties available in Bangladesh. Int Food Res. J. 21(6): 2169-2174

Baloch, MK; Bibi, F (2012). Effect of harvesting and storage conditions on the postharvest quality and shelf life of mango (Mangifera indica L.) fruit. S. Afr. J. Bot. 83: 109-116

Berg, JM; Tymoczko, JL; Stryer, L (2007). Biochemistry (6th ed.). Freeman, WH. Madison Avenue, NY

Escribano, S; Mitcham, EJ (2014). Progress in heat treatments. Stewart Postharvest Rev. 3 (2): 1-6

Herianus, JD; Singh, LZ; Tan, SC (2003). Aroma volatiles production during fruit ripening of Kensington pride mango. Postharvest Biol. Technol. 27(3): 323-336

Joshi, H; Kuna, A; Lakshmi, MN; Shreedhar, M; Kumar, AK (2017). Effect of stage of maturity, ripening and storage on antioxidant content and activity of Mangifera Indica L. var. Manjira, Int. J. Food Sci. Nutr. 2(3): 1-9

Kader, A; Mitcham, B (2008). Optimum procedures for ripening mangoes: fruit ripening and ethylene management. University of California Postharvest Technology Research and Information Centre Publication Series \#9: 47-48. University of California, California

Kong, F; Singh, PS (2013). Effect of processing on the nutrients in foods. In Dillip, G; Bagchi SDD; Smarta, RB (eds.) Innovation in healthy and functional foods, (Chapter 14). CRC Press. Taylor and Francis Group. Boca Raton, Florida: p.616

Kramer, A (1977). Effect of storage on nutritive value of food. J. Food Qual. 1, 23-55. 
Lee, SK; Kader, AA (2000). Preharvest and postharvest factors influencing vitamin $\mathrm{C}$ content of horticultural crops. Postharvest Biol. Technol. 20: 207-220

Moyib, OK; Mkumbira. J; Dixon, AGO; Odunola, OA; Akoroda, MO; Kulakwo, P (2015b). Genetic variation of postharvest physiological deterioration susceptible in a cassava germplasm. Crop Sci. 55, 2701-2711

Moyib, OK; Alashiri, GO; Adejoye, OD (2015a). Chemometric dissimilarity in nutritive value popularly consumed Nigerian brown and white common beans. Food Chem. 166(1): 576-584

Moyib, OK; Adejoye, OD; Sodique, FR (2019). Chemocharacterization and optimization of macro and micro nutrients for exopolysaccharides and mycelia growth in Pleurotus tuberregium (Rumph, ex fr). Food Sci. Technol. (Campinas) 39(2): 286-293

Narayana, K; Pal, RK; Roy, SK (1996). Effect of prestorage treatments and temperature regimes on shelf life and respiratory behaviour of ripe Beneshan mango. J. Food Sci. Technol. (Mysore), 33: 79-82

Normand, F; Lauri, PE; Legave, JM (2015). Climate change and its probable effects on mango production and cultivation. Acta Hortic. 1075: 21-32

Okoth, EM; Sila, DN; Onyango, CA; Owino, WOI; Musyimi, SM.; Mathooko, FM (2013). Evaluation of chemical and nutritional quality attributes of selected mango varieties at three stages of ripeness, grown in lower Eastern province of Kenya - part 2. J Anim Plant Sci. 17 (3): 2619-2630

PFAF, Plant for a Future, 2017. Fruit-Food of the gods. Retrieved from http://www. pfaf.org/user/cmspage .aspx? pageid $=42$

Ravani, A; Joshi. DC (2013). Mango and it's by product utilization-a review. Trends in Postharvest Technol. 1(1): 55-67

Roy, S; Hassan, MK; Rahman, MM; Ahmed, QM; Ahmed, M; Shahadat, MK (2019). Effect of storage period on postharvest, physio-chemical and microbial properties of Fazli and Bombai varieties of mango. J. Biosci. agric. res. 22(2): 1863-1871

Salvia-Trujillo, L; la Peña, MM; Rojas-Graü, A; MartínBelloso, O (2011). Changes in water-soluble vitamins and antioxidant capacity of fruit juice-milk beverages as affected by high-intensity pulsed electric fields (HIPEF) or heat during chilled storage. J. Agric. Food Chem. 59(18): 10034-10043
SAS (2019). Statistical Analysis System University Edition 3, SAS Inc. Cary, NC. USA

Shah, KA; Patel, MB; Patel, RJ; Parmar, PK. (2010). Mangifera indica (mango). Pharmacogn. Rev. 4(7): 42-48

Shi, S; Ma, X; Xu, W; Zhou, Y; Wu, H; Wang, S (2015). Evaluation of 28 mango genotypes for physicochemical characters, antioxidant capacity, and mineral content. J. Appl. Bot. Food Qual. 88: $264-273$

Sogi, DS; Siddiq, M; Roidoung, S; Dolan, KD (2012). Total phenolics, carotenoids, ascorbic acid, and antioxidant properties of fresh-cut mango (Mangifera indica L., cv. Tommy Atkin) as affected by infrared heat treatment. J. Food Sci. 77(11): C1197-C1202

Torres-Leon, C; Rojas, R; Contreras-Esquivel, JC; SernaCock, L; Belmares-Cerda, RE; Aguilar, CN (2016). Mango seed: functional and nutritional properties. Trends Food Sci. Technol. 55: 109-117

Wafula, ENI; Sila, DNI; Wawire, MM (2015). Impact of ripening stage and drying on selected quality attributes of apple mango cubes and leathers. Afr. $J$. Food. Agric. Nutr. Dev. 15(5): 10368-10385

Yi, PPL; Soe, TT; Myint, KT (2020). Postharvest quality of Sein Ta Lone mango (Mangifera indica L.) as affected by different wrapping materials and storage temperature". Acta Sci. Agric. 4 (12): 7-13

Yusuf, A; Rahman, AMA; Zakaria, Z; Wahab, Z; Kumar, SV (2018). Assessment of variability pattern of flesh color in 'Harumanis' mango (Mangifera indica L.) from diverse Perlis geographical origin. Food Res. 2(6): 564-571. 